\title{
Stability and Maturity of Different Poultry Manures and Potential Utilization for Horticultural Production
}

\author{
Mebelo Mataa ${ }^{1}$, Namakau Manzi ${ }^{1} \&$ Kalaluka Munyinda ${ }^{1}$ \\ ${ }^{1}$ School of Agricultural Sciences, Department of Plant Sciences, University of Zambia, P.O. Box 32379, Lusaka, \\ Zambia \\ Correspondence: Mebelo Mataa, School of Agricultural Sciences, Department of Plant Sciences, University of \\ Zambia, Lusaka, Zambia. E-mail: mebelomataa@yahoo.com
}

Received: February 26, 2018

Accepted: March 14, $2018 \quad$ Online Published: July 16, 2018

doi:10.5539/ep.v7n2p1

URL: https://doi.org/10.5539/ep.v7n2p1

\begin{abstract}
This study evaluated stability, maturity and the efficacy of different poultry litter for possible use in container plant production. Three types of poultry manure- Battery cage (BC), Deep litter (DL) and Free range (FR) were used, with Kraal manure (KM) as a comparison. The experiment was set up as a Split- split design with 6 replications. Composting period was main plot, poultry manure type the split plot and mixing ratio as the splitsplit plot. The litter was mixed with garden soil in 2 ratios (3:1 and 1:1 soil: manure ratio) and tested for up to 12 weeks. Rape (Brassica napus) was used as a bioassay for maturity, which was determined at 1 month, 2 months and 3 months. The $\mathrm{pH}$ declined slightly from 7 to about 6 for all treatments except for the kraal manure. Respiration trends were similar to electrical conductivity. Within 2 weeks of curing the respiration rate for all manures declined to below $4 \mathrm{mg} \mathrm{CO} 2^{-} \mathrm{C} / \mathrm{kg}$. At the end of 12 weeks curing Battery cage had highest total nitrogen $(2.32 \%)$, followed by Free range $(1.25 \%)$, Deep litter $(0.73 \%)$ and Kraal manure was lowest at $0.35 \%$ ). Maturity (rape survival) increased with compositing time. After 3 months of curing Kraal manure had highest survivability of rape. The DL at 1:1 ratio had the lowest survival of $67 \%$. At 12 weeks except for BC at 3:1 all treatments had $100 \%$ survival. The results showed that nitrogen rich manures (DL and BC) needed longer curing in order for them to reach maturity.
\end{abstract}

Keywords: battery cage, deep litter, free range, kraal manure, rape (Brassica napus), survivability

\section{Introduction}

The world population has continued to grow and it is projected to plateau at 9 billion in the middle of this century (Godfray et al., 2010). Together with this growing population and increased incomes comes higher consumption and greater demand for processed foods and meat, all of which add to pressure on the food supply system. Poultry is one of the important affordable animal protein sources. Using the year 1960 as a baseline, it has been estimated that there has been almost 5- fold increase in number of chickens produced worldwide (FAOSTAT, 2009). In Zambia, annual poultry production was estimated at 175 million in the year 2015 (Anonymous, 2016). With an annual output of $25 \mathrm{~kg}$ of fresh manure per bird this represents 4,375 million metric tons of manure (Mohamed, 2007). Due to urine and solid wastes being excreted together, poultry manure is rich in nitrogen. However, fresh manure can be injurious to plants and unprocessed manure when stored in open air rapidly loses its $\mathrm{N}$ due to high proteolytic activity (Mohamed, 2007). Thus, it is a challenge to ensure timely processing of poultry manure to prevent rapid decomposition and loss of nutrients (Muller, 1984). Some of the emerging waste management concepts are to change perception of waste being considered as a nuisance to a resource that can be recycled or converted to useful by- products (Brockmann, Pradel \& Helias, 2018). Waste recycling especially in the informal sector has emerged as a livelihood and poverty reduction strategy particularly in the absence of official recycling systems (Uddin \& Gutberlet, 2018).

Over- application of manure results in plants not being able to utilize the contained nutrients thereby exacerbating pollution as excessive nitrates and phosphorus leach into the ground water (Guo et al., 2012). Stability and maturity of manure or compost are often referred to as the compost quality. Stability typically refers to microbial activity and can be defined by the respiration index or the conversion of various chemical species in compost to organic matter. Temperature, age and C: N ratios are important indicators of stability (Gao et al., 2010 and Guo et al., 2012). Maturity refers to the extent of degradation of phytotoxic organic substances and is 
generally measured by the germination index or plant bioassays. Stable and mature compost can be applied to soil as an organic amendment to improve plant growth and soil fertility, as well as enhancing the function of soil for carbon sequestration).The application of unstable and immature compost fixes nitrogen in the soil and restricts plant growth by competing for oxygen in the rhizosphere and releasing toxic substances).

Compost is organic matter that has undergone partial thermophilic, aerobic decomposition- an environmentally safe process is called composting (Raviv, 2005). The combination of different raw materials and the chosen composting method yields products with a wide range of characteristics, in terms of organic matter (OM) content, nutrient content, potential for disease suppresiveness and other physical, chemical, and biological properties (Guo et al., 2012).

Rising costs of chemical fertilizers and growing awareness of the negative impact of agro- chemicals including fertilizers on both the environment and human health call for new agricultural practices (Conservation Farming Unit [CFU], 2017; Sitko et al., 2011). The two common horticultural uses of composts are as soil amendment for vegetable and fruit crops, and as an ingredient in container media (Agro \& Zheng, 2014). The importance of compost's use as a constituent in container media is steadily growing mainly as a result of the increase in the use of container raised plants. Guo et al., (2012) gave three main reasons for increased use of composts is horticulture: 1) Various composts act just as well as peat moss in container media, but their cost is considerably lower. 2) Mature composts may suppress many soil borne diseases. 3) In many cases, non- edible crops, such as ornamentals, forest and garden trees and shrubs, etc., can serve as a safe outlet for composts that may be considered as non- desirable for food crop production. Unlike other treatment methods for organic waste, such as land- filling or incineration, composting does not cause severe pollution due to air pollution or leachates reaching groundwater, (Dalemo, 1999). Raviv (2005) noted the large variety of types of raw materials, composting procedures, and the array of composting durations allows an almost endless permutation of compost types.

This study evaluated the efficacy of different poultry litter as manure and the effect of curing duration and soil: manure mixture ratios needed to turn the litter into usable compost or potting mixture. Rape (Brassica napus) was used as test crop for manure maturity. It is anticipated that the findings of this work will contribute to a better understanding of poultry litter and also assist in developing novel effective utilization systems that have low environmental impact.

\section{Materials and Methods}

\subsection{Location}

The research study was conducted at the University of Zambia, School of Agricultural Sciences Field Station $\left(15^{\circ} 24^{\prime} \mathrm{S}\right.$ and $\left.29^{\circ} 18 \mathrm{E}\right)$, and consisted of field and pot experiments. The pot experiments were carried out in a shade house with about $80 \%$ light transmissivity.

\subsection{Manure Types}

Deep litter manure was obtained from University of Zambia's poultry unit. Broiler chickens were kept in a deep litter system with birds kept in a room with the floor covered with a litter made of course pine wood shavings. The birds' droppings and food spilling from feeders mix with litter. The birds are kept for about 6 weeks and then sold, after which the litter is removed from the house and discarded. Battery cage manure (BC) was obtained from battery cages where birds kept for eggs are raised in multi tired wire cages and fed and watered in these enclosed wire cages. The droppings fall on the floor and are collected periodically. In this study the BC was obtained from Machungwa farm located $25 \mathrm{~km}$ west of Lusaka. Free range manure (FR) was collected from Springfield smallholding in Katuba area, $15 \mathrm{~km}$ north of Lusaka. In the free range system the birds are allowed to roam freely in the homestead and are only housed at night. The system is common in rural communities and typically involves local traditional breeds of chicken. Kraal $(\mathrm{K})$ manure was obtained from the University's Animal Science Department cattle pens where the beef cattle were allowed to graze pastures freely.

\subsection{Manure Composting}

All the four kinds of manures were mixed with garden soil in a ratio of 1:1 on volume basis. The soil had the following characteristics; total nitrogen $(0.11 \%)$, phosphate $\left(\mathrm{P}_{2} 0_{5}\right) 9.40 \mathrm{mg} \mathrm{kg}{ }^{-1} ; \mathrm{K} 0.50 \mathrm{cmol} \mathrm{kg}^{-1} ; 1.37 \%$ carbon and a $\mathrm{pH}$ of 6.56 . The mixture was moistened slightly with water, and care was taken to avoid leaching of nutrients or creation of dump conditions. The soil- manures were mixed homogeneously using a spade. The mixture were piled on a concrete slab and covered with a common black polyethylene sheet. The mixtures were allowed composted for 3 different periods; 1 month, 2 months and 3 months. When they exhibited dryness the mixture was re moistened with addition of small amounts of fresh water of not more than $10 \%$ of the soil/ manure mixture mass. Every two weeks, the materials were turned to improve aeration and samples were 
collected for analysis in the laboratory. The samples were analyzed for the following parameters: 1) $\mathrm{pH}-\mathrm{CaCl}_{2,}$ ) Electric conductivity, 3) Total nitrogen, 4) Organic carbon, 5) Soil respiration.

\subsection{Chemical Analysis}

Total nitrogen $(\mathrm{N})$ was determined by the Kjeldahl digestion-distillation method (Bremner, 1982). Soil organic matter was determined according to the Walkey and Black (1933). Soil pH was determined by using a soil/organic manure water medium at a ratio of 1:2.5 using a digital electronic $\mathrm{pH}$ meter. Pile temperature readings were taken on the day of turning the compost and on the $2^{\text {nd }}$ and $5^{\text {th }}$ day after turning.

\subsection{Manure Maturity and Rape Survivability}

The vegetable used in the growing trials was Brassica napus (rape) cv. Giant rape. The seedlings were raised at the University of Zambia, School of Agricultural Sciences Field station as recommended by Mingochi and Lucheni (2000). After each composting duration treatment, samples of the different manures were collected and mixed with garden soil in two different ratios for planting with rape. The mixing ratio consisted of either of equal volume of compost and soil (1:1) or 3 parts soil with 1 part of compost (3:1). Each treatment was replicated 6 times. The rape seedlings were planted in $15 \mathrm{~cm}$ diameter polyethylene pots with a $180 \mathrm{~cm}^{3}$ volume. Seedlings of rape were transplanted to pots when they were about $10 \mathrm{~cm}$ tall. Leaf number, plant height, leaf area and fresh biomass were monitored.

The test plant used to determine maturity was Brassica napus (rape) cv. Giant rape obtained from Zamseed Co Zambia Ltd. The seedlings were raised at the University of Zambia, School of Agricultural Sciences under standard nursery practices as recommended by Mingochi and Lucheni (2000). The rape seedlings were planted in $15 \mathrm{~cm}$ diameter polyethylene pots with a $180 \mathrm{~cm}^{3}$ volume.

\subsection{Experimental Design}

The experiment was set up as a Split- split design with 6 replications (Sokal \& Rolfe, 1981). Composting period was main plot, poultry manure type the split plot and mixing ratio as the split- split plot. The treatments used were; poultry manures from deep litter managed birds (broilers), battery cage managed birds (layers), free range birds and kraal manure, which was used as a control. The data was subjected to analysis of variance (ANOVA) and means separated using the Least significant difference method. GENSTAT 16 and Microsoft Excel spread sheet software were used to analyze the data.

\section{Results and Discussion}

The type of manure and curing duration had an effect on the chemical and related parameters of the composting product. Secondly, most parameters including the mixing ratios of soil and manure affected the development and yield of the rape test crop.

\subsection{Soil Effects- $p H$, Electrical Conductivity, Respiration and Total Carbon Content}

Figure 1 shows changes in $\mathrm{pH}$, electrical conductivity (EC), respiration and total carbon content during the curing period of the different manures. Over the 12 week period the $\mathrm{pH}$ declined from about 7 to about 6 for all treatments (Figure. 1A) except for the kraal manure which had a higher $\mathrm{pH}$ of about 7. The soil electrical conductivity differed among the different manures from the start and all materials exhibited different trends (Figure. 1B). Electrical conductivity measures the dissolved salts in the soil solution. Therefore high soil conductivity affects the osmolarity of plant cells that will come in contact with such a soil solution. The Battery cage $(\mathrm{BC})$ had the highest $\mathrm{EC}$ at $3.1\left(\mathrm{mS}^{-1} \mathrm{~cm}\right)$, it fell to 1.25 at 4 weeks and then briefly rose to 3 in week 6 , fell to 1.5 before rising to almost the 3 the level at the start of the curing. Kraal manure had the lowest overall EC $0.75 \mathrm{mS}^{-1} \mathrm{~cm}$ at the start of the curing period; it declined slightly but was almost the same at the end of the curing period. The Deep litter and Free range was intermediate between Battery cage and Kraal manure. A rise was noted and the end of the experiment and a similar trend has been noted by other authors as it can impede plant development (Majsztrik, Ristvey \& Lea- Cox. 2011). The EC was highest in Battery cage at $3.1 \mathrm{mS}^{-1} \mathrm{~cm}$.

Soil respiration (Figure. 1C) for the different manures followed trends slightly similar to electrical conductivity especially at the beginning. Battery cage manure at $12 \mathrm{mg} \mathrm{CO}_{2}-\mathrm{C} / \mathrm{kg}$ had highest pre- curing respiration, followed by Free range (7.63), Deep litter (5.4) and Kraal manure lowest at $2 \mathrm{mg} \mathrm{CO} 2^{-} \mathrm{C} \mathrm{kg}^{-1}$. Within 2 weeks of curing the respiration rate for all manures declined to below 4 . The rate remained around this range at the end of the 12 week curing period where at 2.59 the kraal manure had the highest respiration rate and Free range the lowest at $0.94 \mathrm{mg} \mathrm{CO} 2^{-} \mathrm{C} / \mathrm{kg}$. The total carbon content (data not shown) fluctuated without clear pattern between 2 and $3 \%$. 

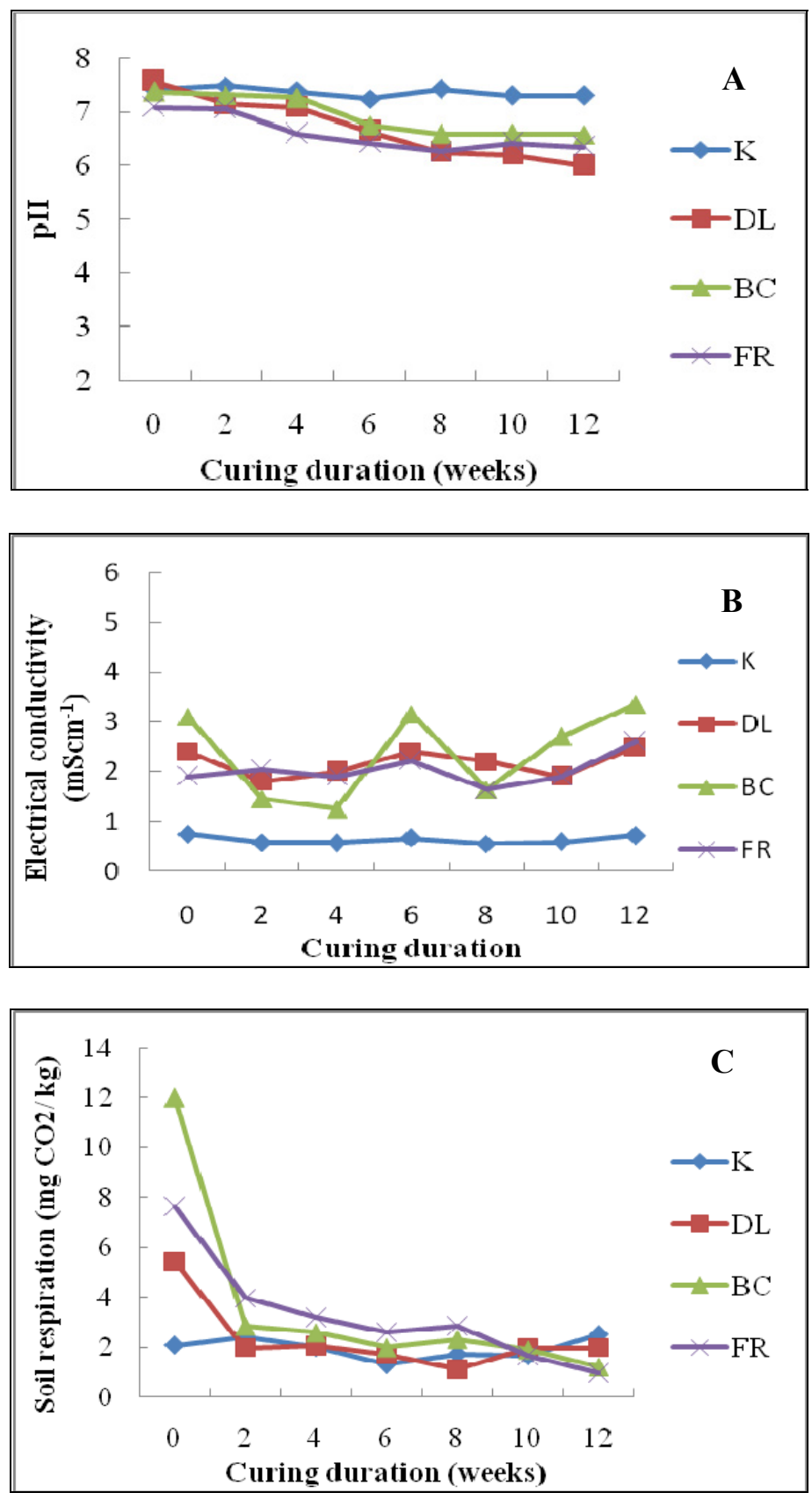

Figure 1. Changes stability parametres of different manures (K- Kraal manure; DL- Deep litter; BC- Battery cage and FR- Free range) cured over a 12 week duration: $\mathrm{pH}(\mathrm{A})$, Electrical conductivity (B), respiration (C) and total carbon (D)

\subsection{Changes in Manure Nitrogen Content}

The nitrogen contents of the different manures are presented in Figure 2. Battery cage manure had highest total nitrogen at $4.41 \%$, followed by Free range manure (3.16\%), Kraal manure (1.27 \%) Deep litter $(1.27 \%)$. The contents declined gradually for all manures. At the end of 12 weeks curing Battery cage litter had highest total nitrogen $(2.32 \%$, followed by Free range at $1.25 \%$, Deep litter $(0.73 \%)$ and Kraal manure the lowest at $0.35 \%)$. Battery cage manure had the highest nitrogen content (4.5\%) this could be due to a number of factors including the relatively long duration it was kept in the cages and thus more time for incorporation of urine and droppings. The concrete floor further prevented the leaching of nutrients. The Free range manure at about $3 \%$ also had high nitrogen content. The Deep litter and Kraal manure had the lowest nitrogen content (1 - $2 \%)$. During curing the nitrogen content declined with curing duration. The decline was consistent in all materials, so that the end of 12 
weeks the concentrations were about $50 \%$ lower in all materials. The decline of nitrogen is said to be due to high proteolytic activity (Mohamed, 2007).

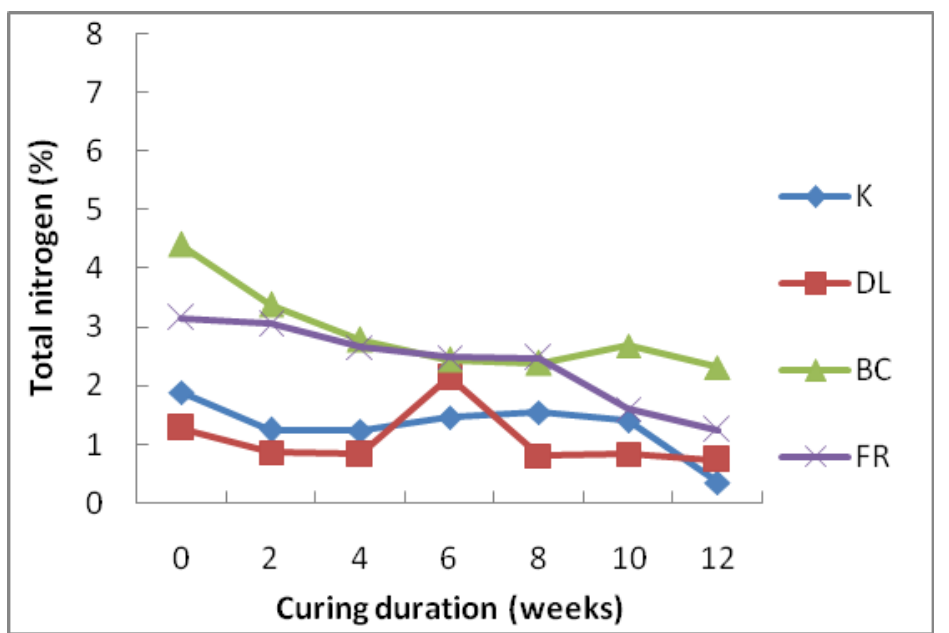

Figure 2. Changes in average nutient content nitrogen of four different manures (K- Kraal manure; DL- Deep litter; BC- Battery cage and FR- Free range) cured over a 12 week period

Soil reaction expressed as $\mathrm{pH}$ is an important parameter determining root development and the ability of media to support plant development (Ivy, Builderback \& Warren, 2002). Initially the manure mixtures had an almost alkaline state but they later became acidic and $\mathrm{pH}$ declined to around 6 . Kraal manure at the end of 12 weeks was at near neutral at around 7, the other 3 had lower $\mathrm{pH}$ close to 6.

\subsection{Effect of Curing Duration, Manure Type and Mixing Ratio on Development and Yield of Rape}

The effects of treatments on plant height and leaf fresh weight are shown in Figure 3. Curing duration and manure type had very highly significant effects $(\mathrm{p} \leq 0.001)$ on plant height but mixing ratio did exert any effect on leaf number. There were significant interactions between manure type and mixing ratio but there were no significant interactions between curing duration, manure type and mixing ratio. Plant height generally increased with curing duration with a slight decline at the 3 month duration. The increase in plant height was higher in the 2 month duration than the 3 month curing duration. The tallest plants were found in $\mathrm{BC}$ manure followed by the DL and FR (there was no difference between these 2). The shortest plants were found under the Kraal manure which was only three quarters of the BC. BC and FR manure had least response to curing duration compared to the other 2 manures. For FR increasing the proportion of manure from 3:1 to 1: 1 reduced plant (by $14 \%$ ) whereas in the Free range the rich mixture had almost $17 \%$ taller plants compared to the weaker mixture. No differences were discernible for the BC and DL. The high manure ratio (1:1) treatments had a phyto toxic effect on plants and in the one month curing duration the Battery cage and Deep litter plants in 1:1 ratio all test plants died. For all the 3 composting durations Kraal manure had significantly shorter plants compared to the other 3 treatments. There was a trend of the $3: 1$ ratio treatments having taller plants compared to the 1:1 ratio treatments (except for the kraal manure where it was the 1:1 plants that were taller), the difference was significant especially for the Free Range treatment.

\subsection{Leaf Weight}

Rape in Zambia is grown for the leaves which are eaten as a vegetable and therefore, the fresh weight is an important production parameter. Leaf weight was influenced significantly by manure curing duration, manure type and mixing ratio with highly significant interactions between all the 3 variables. Leaf weight was lowest in the 1 month duration, increased and reached a maximum at 2 month curing duration and declined at the 3 month duration. Relative to the 1 month duration, the increase was about $50 \%$ for duration 2 and $16 \%$ for duration 3 . The least leaf mass occurred in K, followed by FR, DL and the highest was in the BC which was almost $200 \%$ more than the $\mathrm{K}$ treatment. The rich mixture treatment (1:1) had leaf weight which was $12.6 \%$ heavier compared to the weaker mixture ratio $(3: 1)$ treatment. The interaction between curing duration and manure was very highly significant $(\mathrm{p} \leq 0.001)$. Relative to the 1 month curing, for BC leaf mass increased by $64 \%$ for the 2 month duration and declined by $21 \%$ with the 3 month duration. DL litter was not affected by curing duration. The FR was similar to $\mathrm{BC}$ but the increments were almost twice those of $\mathrm{BC}$. For $\mathrm{K}$ treatments only the 3 month duration 
caused significant increase (108\%) in leaf weight.

Manure type and mixing ratio interacted significantly relative to leaf weight. For BC and DL the 3:1 mixture had more leaf mass (about 20\%) compared to the 1:1 mixing ratio. The FR range did not show any differences based on mixing ratio. In terms duration and mixing ratio, the weak mixture had significantly more leaf weight compared to the rich manure mixture $(\mathrm{p} \leq 0.001)$ except for the 2 month duration where mixing ratio had no effect. Rape varieties grown in Zambia are leafy and therefore appear to be subjected less to effects on plant height compared to leaf mass.

Generally leaf area, was affected by manure type and curing duration and the performance was similar to plant height (Figure 3B). The Kraal manure plants had significantly lower leaf area compared to the other 3 treatments. Leaf mass trends were similar to those of plant height and leaf area. The higher manure to soil ratio treatments (1: 1) had significantly heavier leaves compared to those from low manure to soil ratio treatments (Figure 3C). Battery cage manure had highest rape fresh weight and Kraal manure was lowest in all plant development parameters (weight, height, leaf area and numbers). At 3 months composting in the $\mathrm{BC}$ and $\mathrm{DL}$ and $\mathrm{K}$ manures the rich 1:1 manure soil mixtures had heavier leaf mass compared to 3:1 mixtures. Leaf number was not influenced by the mixing ratio (data not shown) and consequently the only significant interaction was between curing duration and manure type.
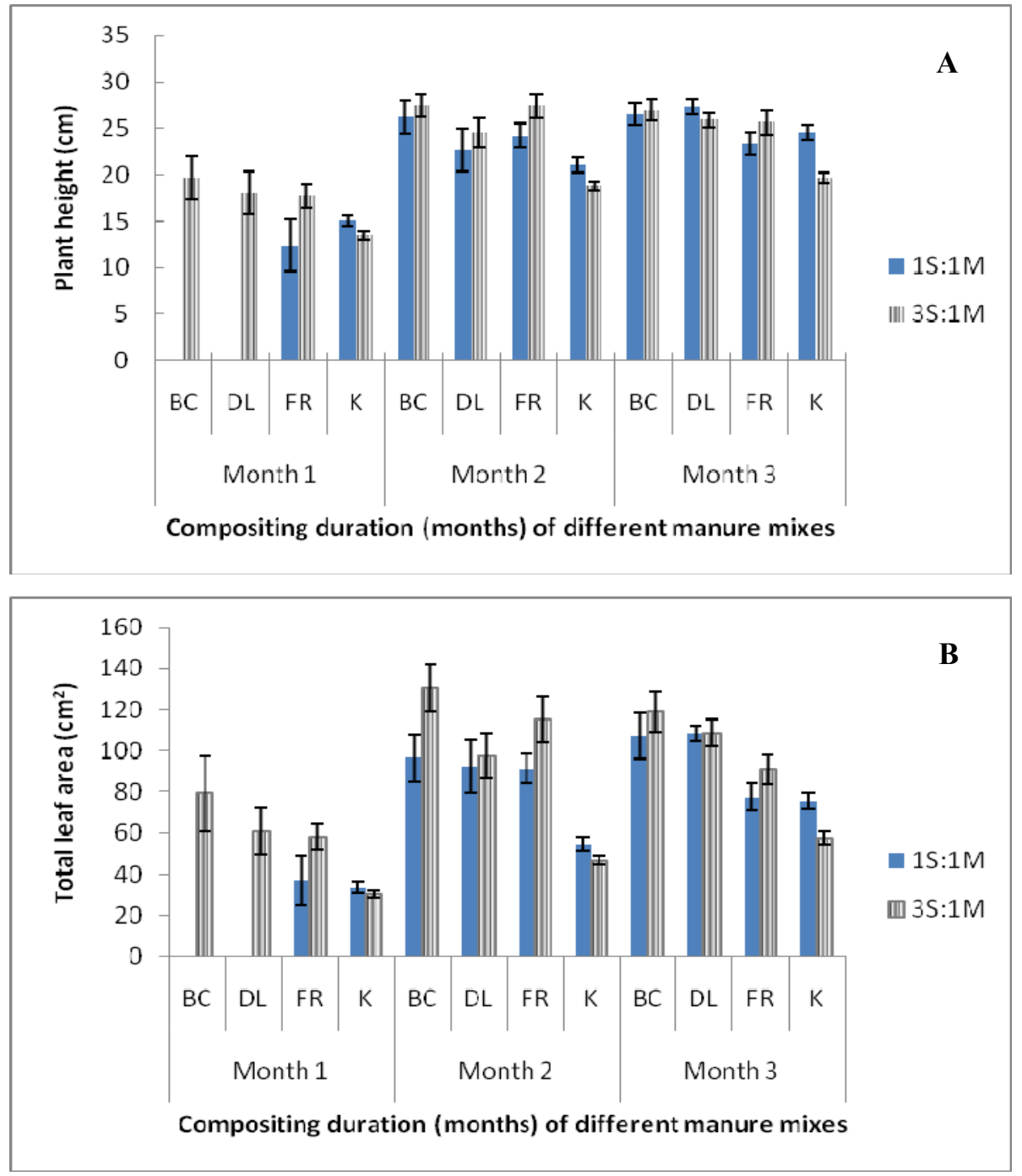


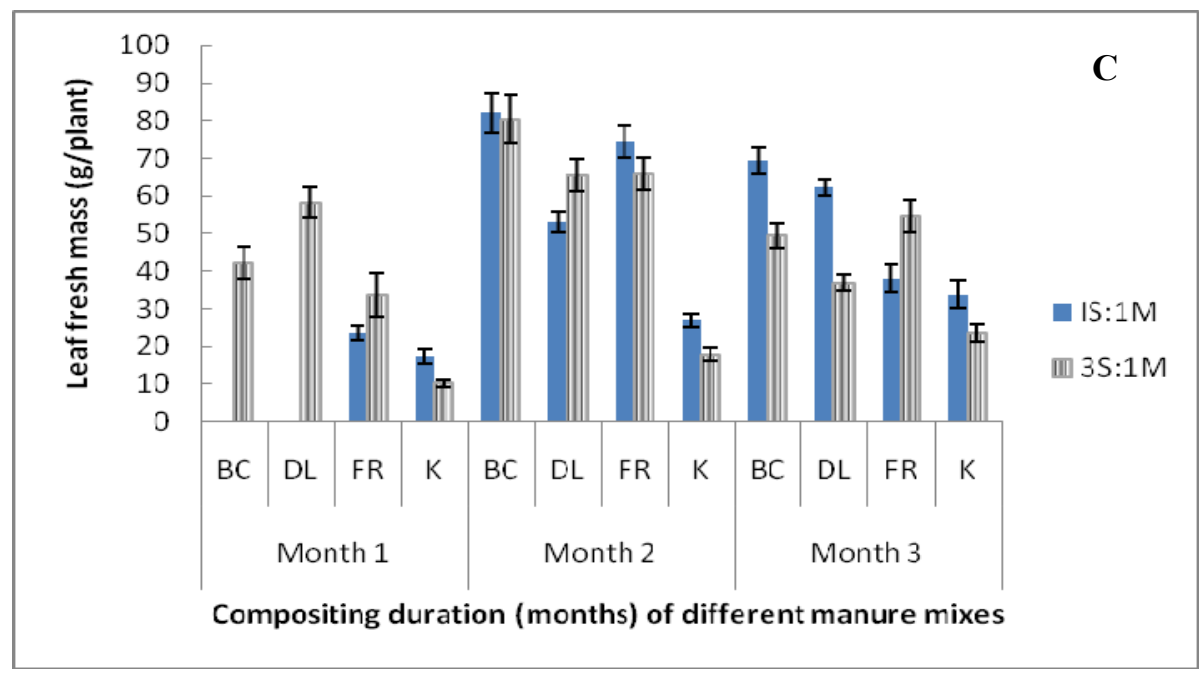

Figure 3. Interactive effects of curing duration, manure types (K- Kraal manure; DL- Deep litter; BC- Battery cage and FR- Free range) and soil manure mixing ratio on plant height (A), leaf area (B) and fresh weight (C) of rape (Brassica napus) test crop. No data for month 1 in the 1:1 ratio plots due to plant mortality

\subsection{Changes in Temperature of Soil Manure Mixtures}

Table 1 shows the changes in temperature during maturation. Generally temperature increased during curing and later on declined. At the start of the curing process all manure mixtures below $18{ }^{\circ} \mathrm{C}$. Thereafter the temp increased, and fell. After 28 days the temp was in the 18 to $21^{\circ} \mathrm{C}$ range. Two days after turning (that was after 28 days of curing) $\mathrm{BC}$ manure had the highest temperature of $41{ }^{\circ} \mathrm{C}$, followed by Deep litter $\left(40{ }^{\circ} \mathrm{C}\right)$ The Kraal manure had the lowest temperature of $36^{\circ} \mathrm{C}$. Five days later all temperatures had gone down; the $\mathrm{BC}$ litter was still high at $33{ }^{\circ} \mathrm{C}$, followed by DL at $32{ }^{\circ} \mathrm{C}$ Kraal at 30 and Free range at $28^{\circ} \mathrm{C}$.

Table 1. Temperature $\left({ }^{\circ} \mathrm{C}\right)$ of soil/ manure mixtures determined at various curing durations

\begin{tabular}{cccccc}
\hline \multirow{2}{*}{$\begin{array}{c}\text { Soil manure } \\
\text { mix }\end{array}$} & \multicolumn{2}{c}{ Temperature (after 28 days curing) } & \multicolumn{2}{c}{ Temperature (after 72 days curing) } \\
\cline { 2 - 6 } & $0^{\mathrm{z}}$ & 2 & 5 & 0 & 2 \\
\hline Deep litter & 19 & 40 & 32 & 24 & 38 \\
Kraal & 18 & 36 & 30 & 22 & 38 \\
Battery cage & 21 & 41 & 33 & 24 & 40 \\
Free range & 20 & 38 & 28 & 25 & 37 \\
\hline
\end{tabular}

${ }^{\mathrm{z}}$ Days after turning of the manure.

At 72 days of curing and periodic turning, the temperatures were higher than at 28 days. They were $25^{\circ} \mathrm{C}$ in Free range, $25^{\circ} \mathrm{C}$ in Deep litter and Battery cage, $22{ }^{\circ} \mathrm{C}$ in Kraal. Two days after turning the highest temperature of 40 ${ }^{\circ} \mathrm{C}$ was recorded in Battery cage, $38^{\circ} \mathrm{C}$ in Kraal and Deep litter. Free range had the lowest at $37^{\circ} \mathrm{C}$.

\subsection{Effect of Curing Duration and Soil: Manure Ratios on Survivability and Yield of Rape}

Table 2 shows the effect of mixing ratio and curing duration on survival of the rape test crop. At 3 months of curing Kraal manure had highest survivability of rape. There was no difference due to mixing rates, both had $100 \%$ survivability. The FR had lowest survivability at $33 \%$. At one month curing for DL and BC the 1:1 ratio caused all plants to die, whereas the 3: 1 mixing ratio had $67 \%$ survival. Survival increased with curing duration. At 2 months curing survival improved in $\mathrm{Dl}$ and $\mathrm{BC}$ which had previously low survival rates. The $\mathrm{BC}$ survival improved to $100 \%$ similar to the Kraal manure. The DL at 1:1 ratio had the lowest rate of $67 \%$. At 12 weeks except for BC at 3:1 all treatments had $100 \%$ survival. 
Table 2. Effect of curing duration and soil: manure mix ratio on survivability of rape (Brassica napus) grown in pots

\begin{tabular}{|c|c|c|c|}
\hline Curing duration (months) & Manure type & Soil: manure ratio & Survivability (\%) \\
\hline \multirow[t]{8}{*}{1} & \multirow[t]{2}{*}{ Kraal } & $1: 1$ & 100 \\
\hline & & $3: 1$ & 100 \\
\hline & \multirow[t]{2}{*}{ Deep litter } & $1: 1$ & 0 \\
\hline & & $3: 1$ & 67 \\
\hline & \multirow[t]{2}{*}{ Battery cage } & $1: 1$ & 0 \\
\hline & & $3: 1$ & 67 \\
\hline & \multirow[t]{2}{*}{ Free range } & $1: 1$ & 33 \\
\hline & & $3: 1$ & 33 \\
\hline \multirow[t]{8}{*}{2} & \multirow[t]{2}{*}{ Kraal } & $1: 1$ & 100 \\
\hline & & $3: 1$ & 100 \\
\hline & \multirow[t]{2}{*}{ Deep litter } & $1: 1$ & 67 \\
\hline & & $3: 1$ & 100 \\
\hline & \multirow[t]{2}{*}{ Battery cage } & $1: 1$ & 100 \\
\hline & & $3: 1$ & 100 \\
\hline & \multirow[t]{2}{*}{ Free range } & $1: 1$ & 100 \\
\hline & & $3: 1$ & 83 \\
\hline \multirow[t]{8}{*}{3} & \multirow[t]{2}{*}{ Kraal } & $1: 1$ & 100 \\
\hline & & $3: 1$ & 100 \\
\hline & \multirow[t]{2}{*}{ Deep litter } & $1: 1$ & 100 \\
\hline & & $3: 1$ & 100 \\
\hline & \multirow[t]{2}{*}{ Battery cage } & $1: 1$ & 100 \\
\hline & & $3: 1$ & 83 \\
\hline & \multirow[t]{2}{*}{ Free range } & $1: 1$ & 100 \\
\hline & & $3: 1$ & 100 \\
\hline
\end{tabular}

Guo et al., (2014) working with pig manures suggested that aeration was the main factor influencing compost stability, while the $\mathrm{C}$ : $\mathrm{N}$ ratio mainly contributed to compost maturity, and moisture content had an insignificant effect on the compost quality. Turning the manure promoted air exchange and in the process increased oxygen levels which may have increased microbial activity and resulted in increase in soil/ manure stability. This trend was in line with changes in respiration rates, total carbon and also temperature. Generally Battery cage manure which had the highest nitrogen content generally maintained the highest temperatures and kraal manure which had lowest nitrogen also had lowest temperature. Wang et al. (2004) suggested that composts from cattle and pig manure were more stable when the respiration rates were below $1 \mathrm{mg} \mathrm{CO}_{2}-\mathrm{C} \mathrm{g}^{-1} \mathrm{DM} \mathrm{d}^{-1}$. Higher $\mathrm{CO}_{2}$ emissions indicate unstable compost that needs further decomposition. In our study we found that Kraal manure had respiration below this threshold and was able to better rape survival. Plant survival was influenced largely by $\mathrm{pH}$, respiration and curing duration.

Bernal, Albuquerque \& Moral (2009) noted that the application of unstable and immature compost fixes nitrogen in the soil thereby restricting plant growth by competing for oxygen in the rhizosphere and releasing toxic substances. Our results indicated that Battery Cage and Deep litter manures were high in nitrogen compared to Kraal manure or manure obtained from Free range chickens. However, the rich manures needed longer curing durations in order for them to mature. Increasing the use of manures in agriculture presents an effective and profitable means of disposal of poultry litter and also this prevents environmental pollution.

Our study revealed the heterogeneity of different poultry manures and the best ways to ensure effective use. 
Plant performance was negatively affected especially in the one and two month durations.

\section{Conclusion}

The period starting mid- 1980s, has witnessed a growing trend of intensified nursery production (Agro \& Zheng, 2014). Containerized plant production has been noted to be a major contributor to this intensification because it allows greater production per hectare, higher quality and faster growth (Agro \& Zheng, 2012). There are however risks associated with container production such as higher nutrient leaching in container- grown plant culture that need attention (Majsztrik, Ristvey \& Lea- Cox., 2011). The manures tested in this study have potential usefulness in container plant production which is an emerging important system for raising and maintaining plants in horticulture.

\section{Acknowledgement}

The technical guidance on analytical procedures by Mr. Gideon Musukwa of the Soil Science Department, University of Zambia is most appreciated.

\section{References}

Agro, E., \& Zheng, Y. (2014). Controlled- release fertilizer application rates for container nursery crop production in Southwestern Ontario, Canada. HortScience, 49, 1414-1423.

Anonymous. (2016). Fisheries and Livestock Statistics. Department of Veterinary and Livestock Development Report. Government of Republic of Zambia.

Bernal, M. P., Albuquerque, J. A., \& Moral, R. (2009). Composting of animal manures and chemical criteria for compost maturity assessment. A review. Bioresource Technology, 100, 5444-5453. https://doi.org/10.1016/j.biortech.2008.11.027

Bray, P. H, \& Kurtz, L. T. (1945). Determination of total organic and available forms of phosphorus in soils. Soil Science, 59, 39-45. https://doi.org/10.1097/00010694-194501000-00006

Bremner, J. M., \& Mulvancy, C. S. (1982). Nitrogen-Total. In A. L. Page et al (Eds.), Methods of soil analysis Part 2, Agronomy Monogram. 9 (2nd ed., pp. 403-430). ASA and SSSA, Madison, Wsc.

Brockmann, D., Pradel, M., \& Helias, A. (2018). Agricultural use of organic residues in life cycle assessment: Current practices and proposal for the computation of field emissions and of the nitrogen mineral fertilizer equivalent. Resources, conservation and recycling, 133, 50-62. https://doi.org/10.1016/j.resconrec.2018.01.034

Conservation Farming Unit. (2017). Conservation farming unit: A reference handbook for managers, professionals and promoters. The practice of conservation farming and climate smart agriculture in Zambia's Agro-ecological Regions I and II A. Retrieved from www.conservation agriculture.org

Dalemo, M. (1999). Environmental systems analysis of organic waste management: The ORWARE model and sewage plant and anaerobic digestion submodels. Acta Universtatis Agriculturae Sueciae Agraria No. 146.

FAOSTAT. (2009). Retrieved from http://faostat.fao.org/default.aspx

Gao, M., Li, B., Yu, A., Liang, F., Yang, L., \& Sun, Y. (2010). The effect of aeration rate on forced-aeration composting of chicken manure and sawdust. Chemosphere, 78, 614-619. Retrieved from www.elsevier.com/locate/chemosphere

Godfray, H. C., Beddington, J. R., Cute, I. R., Haddad, L., Lawrence, D., Miur, J. F. ... Toulmin, C. (2010). Food security: The challenge of feeding 9 billion people. Science, 327, 812-818. https://doi.org/10.1126/science. 1185383

Guo, R., Li, G., Jiang, T., Schuchardt, F., Chen, T., Zhao, Y., \& Shen, Y. (2012). Effect of aeration rate, C/N ratio and moisture content on the stability and maturity of compost. Bioresource Technology, 112, 171-178. https://doi.org/10.1016/j.biortech.2012.02.099

Hichaambwa, M., \& Tschirley, D. (2006). Horticultural Rapid Appraisal: Understanding Value Chains of Fresh Fruits and Vegetables. Working Paper 17. Food Security Research Project. Zambia. Retrieved from http://www.aec.msu.edu/agecon/fs2/zambia/index.htm

Ivy, R. L., Builderback, T. E., \& Warren, S. L. (2002). Date of potting and fertilization affects plant growth mineral content and substrate electrical conductivity. Journal of Environmental Horticulture, 20, 104-109.

Majsztrik, J. C., Ristvey, A. J. G., \& Lea- Cox, J. D. (2011). Water and nutrient management in the production of container- grown ornamentals. Hort Review, 38, 253-296. 
Mingochi, D. S., \& Lucheni, S. W. (2000). Improved vegetable practices for smallholder farmers in Zambia: $A$ reference manual for field extension workers. Field document No. 1. FAO and Ministry of Agriculture, Food and Fisheries. Lusaka, Zambia.

Mohamed, A. M. (2007). Nutrient release pattern during composting poultry manure. Research Journal of Agriculture and Biological Science, 3, 306-308.

Muller, Z. O. (1984). Feed from animal waste: Feeding manual, FAO animal production and health paper. No. 28.

Raviv, M. (2005). Production of high- quality composts for horticultural purposes: A mini review. Hort Technology, 15, 52-57.

Sitko, N. J., Chapoto, A., Kabwe, S., Tembo, S., Hichaambwa, M., Lubinda, R. ... Nthani, D. (2011). Technical Compendium: Descriptive Agricultural Statistics and Analysis for Zambia in Support of the USAID Mission's Feed the Future Strategic Review. Food Security Collaborative Working Papers. Michigan State University, Department of Agricultural, Food, and Resource Economics. Retrieved from http://www.aec.edu/agrecon/fs2/zambia/index.htm

Uddin, S. M. N., \& Gutberlet, J. (2018). Livelihoods and health status of informal recyclers in Mongolia. Resources, conservation and recycling, 134, 1- 9. https://doi.org/10.1016/j.resconrec.2018.02.006

Walkley, A., \& Black, J. A. (1934). An examination of the Degtjareff method for determining soil organic matter, and a proposed modification of the chromic acid titration method. Soil Science, 37, 29-38. https://doi.org/10.1097/00010694-193401000-00003

Wang, P., Changa, C. M., Watson, M. E., Dick, W. A., Chen, Y., \& Hoitink, H. A. J. (2004). Maturity indices for composted dairy and pig manures. Soil Biology and Biochemistry, 36, 767-776. https://doi.org/10.1016/j.soilbio.2003.12.012

\section{Copyrights}

Copyright for this article is retained by the author(s), with first publication rights granted to the journal.

This is an open-access article distributed under the terms and conditions of the Creative Commons Attribution license (http://creativecommons.org/licenses/by/4.0/). 